Original Research Paper

\title{
Pengembangan Potensi Wisata untuk Meningkatkan Daya Tarik Wisatawan di Desa Ketapang Raya Kecamatan Keruak Kabupaten Lombok Timur
}

\author{
Gemma Maya Gustin¹, M. Fahmi Khairul Umam¹, Hafizul Khatomy², Tiara Karantina², Widia Ningsih", \\ Abdul Syukur 4 \\ ${ }^{I}$ Fakultas Matematika dan Ilmu Pengetahuan Alam, Universitas Mataram, Mataram, Indonesia; \\ ${ }^{2}$ Fakultas Pertanian, Universitas Mataram, Mataram, Indonesia; \\ ${ }^{3}$ Fakultas Teknologi Pangan, Universitas Mataram, Mataram, Indonesia. \\ ${ }^{4}$ Program Studi Magister Pendidikan IPA, Pascasarjana, Universitas Mataram, Mataram, Indonesia.
}

DOI: https://doi.org/10.29303/jpmpi.v4i2.720

Sitasi: Gustin, G. M., Umam, M. F. K., Khatomy, H., Karantina, T., Ningsih, W., \& Syukur. A. (2021). Pengembangan Potensi Wisata untuk Meningkatkan Daya Tarik Wisatawan di Desa Ketapang Raya Kecamatan Keruak Kabupaten Lombok Timur. Jurnal Pengabdian Magister Pendidikan IPA, 4(2)

\section{Article history}

Received: 23 Maret 2021

Revised: 20 Mei 2021

Accepted: 22 Juni 2021

*Corresponding Author: Widia Ningsih, Fakultas Teknologi Pangan, Universitas Mataram, Mataram, Indonesia;

Email:

widianingsih019@gmail.com

\begin{abstract}
Pengembangan potensi pariwisata merupakan salah satu upaya untuk meningkatkan daya tarik wisatawan. Desa Ketapang Raya menjadi salah satu desa wisata di Kecamatan Keruak, kabupaten Lombok Timur. Desa ini memiliki beberapa potensi berupa wisata pantai, hutan Mangrove, sentral garam, dan budidaya hasil laut. Sehingga, melalui Kuliah Kerja Nyata (KKN) ini dapat membantu mendukung sektor wisata di Desa Ketapang Raya. Tujuan dari kegiatan ini adalah untuk mempromosikan destinasi-destinasi wisata guna pengembangan pariwisata, meningkatkan daya tarik pengunjung (wisatawan), dan untuk meningkatkan pendapatan masyarakat. Kegiatan ini dilakukan melalui 3 tahap yaitu pertama persiapan promosi, kedua pembuatan sarana dan prasarana dan ketiga pendampingan masyarakat untuk pengembangan usaha transit. Manfaat dari kegiatan ini adalah dapat memperkenalkan objek wisata, dapat meningkatkan perekonomian masyarakat dan dapat meningkatkan daya tarik pengunjung (wisatawan) di Desa Ketapang Raya. Hasil dari program kerja ini yaitu tereksplorasinya beberapa destinasi melalui usaha transit, meningkatkan pendapatan masyarakat di daerah wisata, serta adanya peningkatan sarana dan prasarana wisata berupa papan informasi, papan himbauan, spot foto dan sarana pendukung lainnya.
\end{abstract}

Keywords: Potensi; Objek Wisata; Destinasi; Desa Ketapang Raya.

adanya budaya disekitar lingkungan yang bersifat informatif dan partisipatif yang memiliki tujuan menjamin kelestarian alam dan sosial-budaya. Ekowisata pada dasarnya fokus pada tiga hal utama

yaitu; keberlangsungan alam atau ekologi, memberikan dampak manfaat pada ekonomi, dan secara psikologi dapat diterima dalam kehidupan sosial masyarakat di lingkungan ekowisata. Kegiatan ekowisata ini memberi kesempatan kepada semua orang untuk dapat melihat, mengetahui, dan menikmati alam, intelektual dan budaya masyarakat lokal (Dias, 2009). 
Industri wisata menjadi salah satu strategi yang digunakan pemerintah atau swasta untuk wilayah tertentu untuk mempromosikan wilayah tersebut sebagai daerah tujuan wisata untuk meningkatkan perekonomian masyarakat sekitar wilayah wisata dan menjadi lahan lowongan kerja (Budhyana, 2008). Wilayah pesisir dan laut yang dapat dikembangkan menjadi kawasan wisata berupa pemandangan pantai yang indah dan keaslian lingkungan seperti kehidupan dibawah air. Pantai sebagai tempat pengembangan ekowisata merupakan suatu jasa lingkungan yang cenderung akan memberikan manfaat pada kepuasaan batin seseorang melihat pantai yang mengandung nilai estetika (Ali, 2004) Indonesia sebagai Negara yang berkepulauan memiliki banyak pantai dengan keindahannya sendiri, salah satu pulau di Indonesia yang memiliki potensi ekowisata yang tinggi adalah provinsi Nusa Tenggara Barat, Lombok. Nusa Tenggara Barat memiliki Sembilan kabupaten/kota, salah satunya adalah Lombok Timur. Lombok Timur terkenal sebagai tujuan wisata karena pantainya yang indah. Dinas Pariwisata Kabupaten Lombok Timur mencatat ada sebelas pantai di Lombok Timur yang dijadikan sebagai objek wisata. Objek wisata pantai Lombok Timur memiliki bentang alam yang indah, air laut yang jernih dan biota bawah laut yang sangat indah untuk dilihat, salah satunya yang dimiliki oleh Pantai Lungkak di Ketapang Raya (Sabhani, 2010).

Desa Ketapang Raya adalah Desa baru yang lahir secara dejure namun secara definitif sudah menjadi Desa sejak Oktober 2010. Desa Ketapang Raya adalah desa baru yang lahir dari pemekaran desa induk Desa Tanjung Luar. Desa Ketapang Raya berdiri secara resmi sebagai status Desa Persiapan pada tanggal 21 Mei 2010 melalui Peraturan Bupati Lombok Timur No. 16 Tahun 2010. Sebagai desa baru, Desa Ketapang Raya terus berbenah untuk mengatasi masalah internal desa, mengembangkan Sumber Daya Alam (SDA) dan Sumber Daya Manusia (SDM) dan beberapa masalah yang kaitannya dengan fasilitas pendukung untuk meningkatkan perekonomian dan kesejahteraan masyarakat.

Secara geografis, Desa Ketapang Raya adalah daerah pesisir dan beriklim tropis. Umumnya Desa Ketapang Raya memiliki dua musim yaitu musim hujan dan musim kemarau. Suhu udara di desa tersebut berkisar antara $27^{0}-38^{0}$ $\mathrm{C}$, dengan curah hujan rata-rata $1006,5 \mathrm{~mm} /$ tahun.

\section{Desa Ketapang Raya berada di 1160300 24,940 BT dan $080470340 \mathrm{LS}$.}

Desa Ketapang Raya terletak berbatasan dengan beberapa desa yaitu di sebelah utara berbatasan langsung dengan Desa Pijot dan Desa Tanjung Luar, sebelah selatan berbatasan dengan Desa Jerowaru, sebelah timur Desa Ketapang Raya berbatasan langsung dengan Teluk Jukung dan di sebelah barat berbatasan dengan Desa Dane Rase.

Sumber daya alam di Desa Ketapang Raya meliputi sumberdaya alam non hayati yaitu: air, lahan, udara dan bahan galian, sedangkan sumberdaya alam hayati yaitu pesisir dan laut, flora dan fauna. Pada tataguna dan intensifikasi lahan yang ada di Desa Ketapang Raya sebagai berikut Pertambakan udang/ikan seluas $17 \mathrm{Ha}$, tambak Garam $28 \mathrm{Ha}$, persawahan seluas $85.32 \mathrm{Ha}$, perkebunan seluas $63,73 \mathrm{Ha}$, Permukiman seluas $101.09 \mathrm{Ha}$, perkantoran/Fasilitas umum seluas 24 are. Fasilitas dan SAB seperti sumur gali, PDAM, penyulingan air 1 Unit, perlindungan mata air 3 titik, perpipaan mata air. Masyarakat Desa Ketapang Raya terdiri dari suku Sasak, Suku Mandar, Suku Arab dan Suku Ende. Bahasa Seharihari adalah Bahasa Sasak dan Bahasa Bajo, asal Suku masayarakat Desa Ketapang Raya adalah Suku Mandar yang identik dengan Pelaut sehingga sebagian besar mata pencaharian masyarakat adalah Nelayan.

Desa Ketapang Raya terdiri dari enam dusun yaitu Dusun Pelebe, Dusun Lungkak, Dusun Telage Bagik, Dusun Kedome, Dusun Lungkak Selatan dan Dusun Lungkak Utara. Jumlah penduduk 4.926 jiwa diantaranya laki-laki 2.271 jiwa dan perempuan 2.655 jiwa. Penduduk menurut strata pendidikan yaitu Sarjana (S1, S2, S3) sebanyak 28 orang, diploma (D1, D2, D3) sebanyak 39 orang SLTA/sederajat, 399 orang, 611 orang, SD/sederajat 1.794 orang sedangkan yang buta aksara dari usia 07-15 tahun sebanyak 150 orang, usia $>15-45$ tahun sebanyak 250 orang dan usia $>45$ tahun ke atas sebanyak 390 orang.

Desa Ketapang Raya sebagai daerah pesisir pantai dengan kondisi alam yang masih alami dan mudah diakses menjadikannya sebagai salah satu kawasan ekowisata yang berpeluang bagus untuk dikembangkan, selain itu juga pengembangan ekowisata di Desa Ketapang Raya memiliki makna yang strategis untuk peluang membuka lapangan kerja bagi masyarakat setempat. Sebagai daerah 
dengan potensi wisata alam yang bagus, Desa Ketapang Raya memiliki keunggulan diantaranya:

1) Desa Ketapang Raya termasuk dalam daerah pesisir maka salah satu keunggulan yang dimiliki adalah berupa pantai. Pantai yang dimiliki oleh Desa Ketapang Raya sangat mudah diakses melalui jalan utama Keruak - Jalan Kedome dan dari kota kabupaten selang jaraknya $\pm 20 \mathrm{~km}$. Pantai menjadi salah satu objek wisata yang menarik untuk dikunjungi oleh wisatawan, selain keindahan pantainya juga terdapat beberapa spot foto. Salah satu potensi spot foto yang disajikan di pantai Desa Ketapang Raya adalah Padang savana, yaitu hamparan padang savana yang luas di pinggir pantai Desa Ketapang Raya tepatnya di Dusun Lungkak. Tersedia juga destinasi transit yaitu jasa perahu untuk wisatawan yang ingin menyeberang ke beberapa tempat wisata seperti Gili Petelu, Pulau Pasir, Pantai Segui, Gili Sunut, Pantai Semankok dan Pantai Tangsi.

2) Hutan Mangrove di Desa Ketapang Raya memiliki potensi yang bagus untuk dikembangkan karena fungsi dari hutan Mangrove tersebut untuk daerah pesisir bukan hanya sebagai pelindung dari air laut yang terkadang naik atau secara fisik. Namun, ekosistem terumbu karang dan ekosistem padang lamun. Hutan Mangrove disini juga bukan hanya memiliki keuntungan untuk menjaga ekosistem yang ada di pantai namun memiliki peran penting bagi kehidupan nelayan mengingat sebagian besar masyarakat di Desa Ketapang Raya dalih sebagai Nelayan.

3) Budidaya Teripang menjadi salah satu potensi unggulan yang dimiliki oleh Desa Ketapang Raya. Bagaimana tidak, ekosistemnya yang cocok untuk budidaya teripang yaitu ekosistem terumbu karang dan lamun yang emang Desa Ketapang Raya sudah miliki menjadikannya desa pembudidaya teripang. Budidaya teripang juga cocok untuk perairan yang ada di Desa Ketapang Raya yang bersih dan salinitas air lautnya yang normal dan pantai berpasir halus. Keberadaan hutan Mangrove dan lamun yang menjadi pelindung dari hempasan ombak juga menjadi salah satu keunggulan yang dimiliki Desa Ketapang Raya untuk budidaya teripang.
Potensi ekowisata di Desa Ketapang Raya yang disebutkan diatas merupakan keunggulan yang dapat dikembangkan sebagai objek wisata. Lombok Timur adalah kawasan objek wisata bagian selatan yang mulai berkembang. Oleh karena itu, Desa Ketapang Raya telah merencanakan dalam pembangunan desa untuk mengembangkan ekowisata. Potensi yang mendukung pengembangan ekowisata di Desa Ketapang Raya adalah infrastruktur jalan.

\section{Metode}

\section{A. Persiapan}

Tahapan Persiapan melalui program yang telah dilakukan oleh Tim pengabdian masyarakat Kuliah Kerja Nyata (KKN) di Desa Ketapang Raya diantaranya meliputi:

1) Persiapan materi tentang manajemen ekowisata seperti: peningkatan pengetahuan dan keterampilan dalam mengelola ekowisata, menentukan model ekowisata dalam bentuk pemanfaatan jasa lingkungan untuk pelestarian lingkungan, nilai ekonomi dan sosial ekowisata bagi masayarakat desa, kekuatan kelompok dalam pengembangan ekowisata, dan pengelolaan ekowisata secara terpadu dan berkelanjutan.

2) Persiapan materi tata kelola potensi ekowisata sebegai sumber mata pencaharian berkelanjutan,

3) Persiapan materi potensi kearifan masyarakat untuk mendukung pengembangan ekowisata

4) Persiapan desain model promosi ekowisata alam di Desa Ketapang Raya.

\section{B. Pelaksanaan Pengembangan ekowisata di Desa Ketapang Raya}

Berdasarkan solusi dari permasalahan seperti yang telah diuraikan di atas membutuh metode pelaksanaan yang relevan. Beberapa metode yang digunakan adalah:

1) Sosialisai, pada tahap ini Tim mensosialisaikan tema program pada pemerintah Desa, tokoh masyarakat dan stakehoulder lainnya. Metode yang digunakan adalah diskusi. Tujuan pada program sosialisai adalah untuk memperoleh pemahaman yang sama tentang pentingnya pengembangan ekowisata sebagai sumber mata 
pencaharaian berkelanjutan masyarakat di Desa Ketapang Raya.Selain itu disampaikan luaran yang perlu dicapai dari tiap solusi permasalahan.

2) Metode Pelatihan kepada pemuda karang taruna, POKDARWIS (Kelompok Sadar Wisata), dan BUMDES (Badan Usaha Milik Desa), metode ini menggunakan modul yang dikembangkan sesuai dengan tiap solusi dari permasalahan seperti yang telah diuraikan di atas. Dalam setiap modul terdiri dari empat bagian yang terdiri dari: (a) langkah-langkah yaitu uraian yang menjelaskan langkah demi langkah yang dapat dilakukan oleh fasilitator dalam memfasilitasi kegiatan pelatihan pada tiap program, (b). bahan bacaan adalah materi bacaan yang dapat dijadikan referensi bagi fasilitator atau pelatih mengenai isi materi yang akan disampaikan dan (3) lembar kegiatan yang merupakan lembar aktivitas yang digunakan peserta dalam proses pembelajaran dan slide presentasi

3) Fokus Group Diskusi (FGD) adalah metode yang digunakan berdasarkan relevansi tiap solusi, hal ini sangat penting untuk memperoleh informasi mengenai beberapa pertanyaan tentang bagaiamana dan mengapa kita butuhkan ekowisata sebagai sumber matapencaharian yang berkelanjutan bagai masyarakat di Desa Ketapang Raya.

4) Monitoring dan Evaluasi, metode ini digunakan untuk memberikan hasil pemahaman secara komprehensif bagai tiap stakehouder sesuai dengan solusi dari tiap permasalahan pada pengembangan ekowisata yang telah dilakukan di Desa Ketapang Raya.

5) Model contoh, metode ini akan didesaian dalam memilih kelompok kecil masyarakat atau lingkungan sosial pada level dusun berdasarkan kesepakan dari semua unsur pemerintah desa dan tokoh masyarakat yang lain untuk menerapakan solusi dari semua permasalahan dalam pengembangan ekowisata di Desa Ketapang Raya.

\section{Hasil dan Pembahasan}

Kegiatan KKN (Kuliah Kerja Nyata) bertemakan wisata yang dilaksanakan di Desa Ketapang Raya, Kecamatan Keruak, kabupaten Lombok Timur dapat dikatakan berjalan dengan baik sesuai dengan program-program yang direncanakan. Program merupakan pernyataan yang berisi kesimpulan dari beberapa harapan atau tujuan yang saling bergantung dan saling terkait, untuk mencapai suatu sasaran yang sama (Muhaimin et al, 2009). Biasanya suatu program mencakup seluruh kegiatan yang berada di bawah unit administrasi yang sama, atau sasaran-sasaran yang saling bergantung dan saling melengkapi, yang semuanya harus dilaksanakan secara bersamaan atau berurutan. Program yang dilakukan lebih berarah kepada pendampingan untuk pengembangan objek wisata dan pendukung wisata yang ada di desa Ketapang Raya. Beberapa program yang dapat direalisasikan pada berarah kepada pengembangan potensi-potensi desa Ketapang Raya berbas digital dan media, diantaranya yaitu:

\section{1) Survey Potensi untuk Promosi Digital}

Potensi desa merupakan keseluruhan sumber daya yang dimiliki atau digunakan oleh desa, baik sumber daya manusia dan sumber daya alam. Untuk mendukung percepatan kesejahteraan masyarakat disuatu daerah diperlukannya pendataan potensi yang berada di desa untuk menghasilkan data yang spesifik bagi keperluan pembangunan wilayah (Cambali dan Untoro, 2017). Dalam kegiatan ini pendataan potensi berarah kepada potensi wisata dan pendukung wisata yang ada di desa Ketapang Raya untuk di kembangkan pada website atau media lain. Beberapa potensi yang ada di desa Ketapang Raya yang merupakan potensi wisata dan pendukung wisata diantaranya yaitu: Pantai Lungkak, Ekosistem Mangrove, Tambak Lobster, Produksi Garam, dan Tambak Teripang.

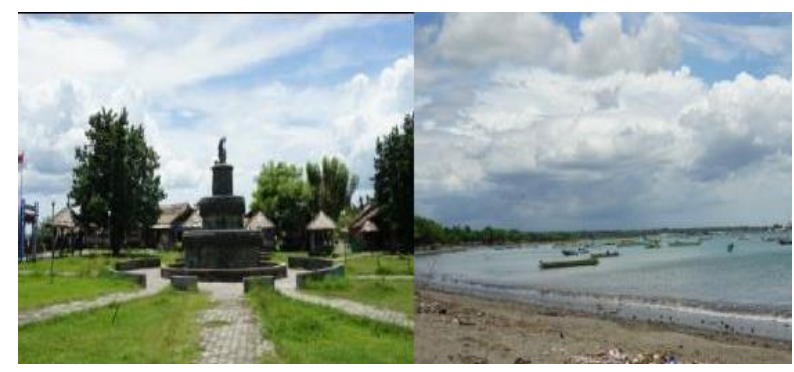

(a) 


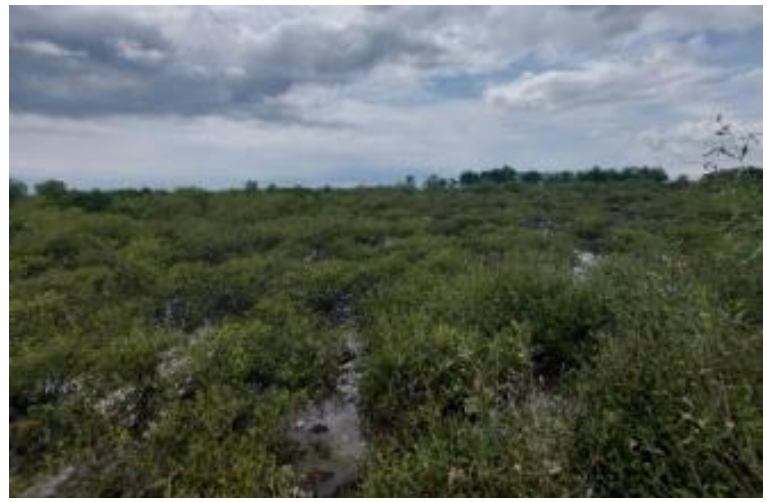

(b)

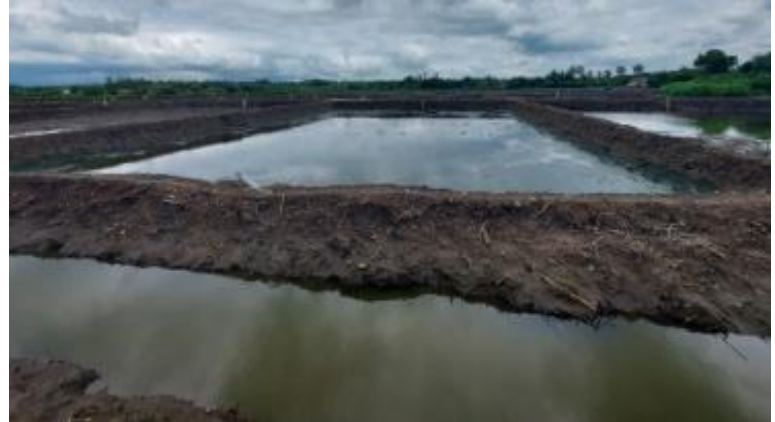

(c)

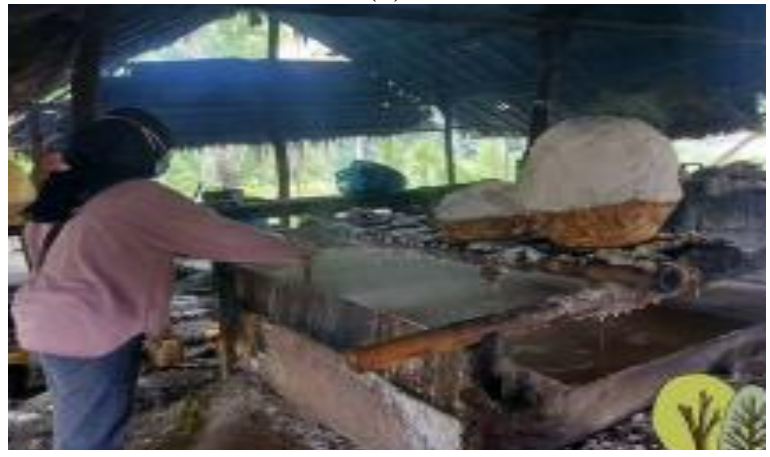

(d)

Gambar 1. (a) taman dan Pantai Lungkak (b) ekosistem Mangrove (c) Tambak Teripang (d) Produksi Garam.

\section{2) Pembuatan Sarana dan Prasarana}

Menurut kamus besar Bahasa Indonesia sarana adalah segala sesuatu yang dapat dipakai sebagai alat dalam mencapai maksud atau tujuan. Sedangkan prasarana adalah segala sesuatu yang merupakan penunjang utama terselenggaranya suatu proses (usaha, pembangunan, proyek). Dalam kegiatan pengembangan potensi wisata di desa Ketapang Raya ini meliputi membuat beberapa sarana dan prasarana penunjang wisata di desa Ketapang Raya seperti: (1) Penunjuk Jalan yang bertujuan untuk memudahkan pengunjung dalam menjangkau lokasi wisata ; (2) Papan Informasi dibuat sebagai pusat informasi bagi pengunjung agar dapat mengetahui potensi yang ada di desa Ketapang Raya; dan (3) Papan himbauan dalam menerapkan wisata berbasis konservasi lingkungan yaitu berupa himbawan kepada masyarakat agar tetap menjaga keberishan lingkungan untuk meningkatkan kenyamanan.

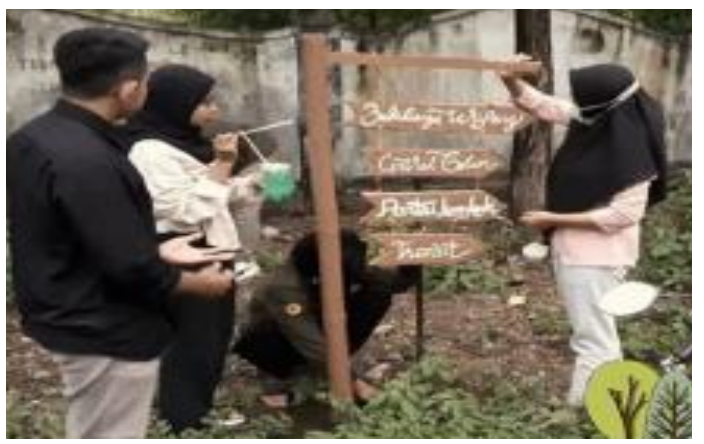

(a)

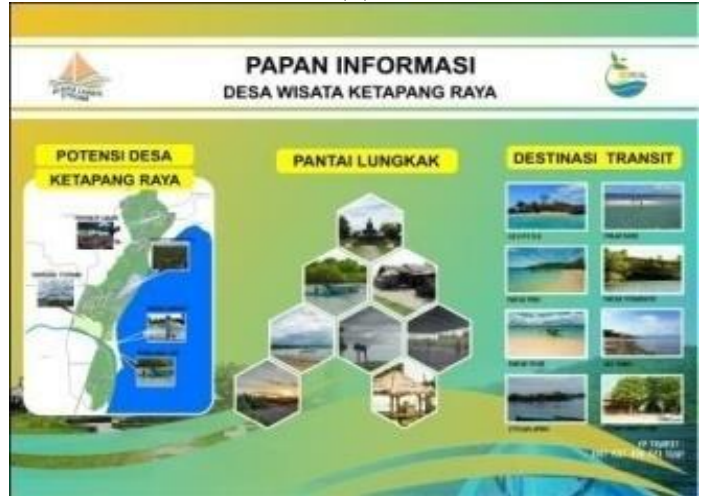

(b)

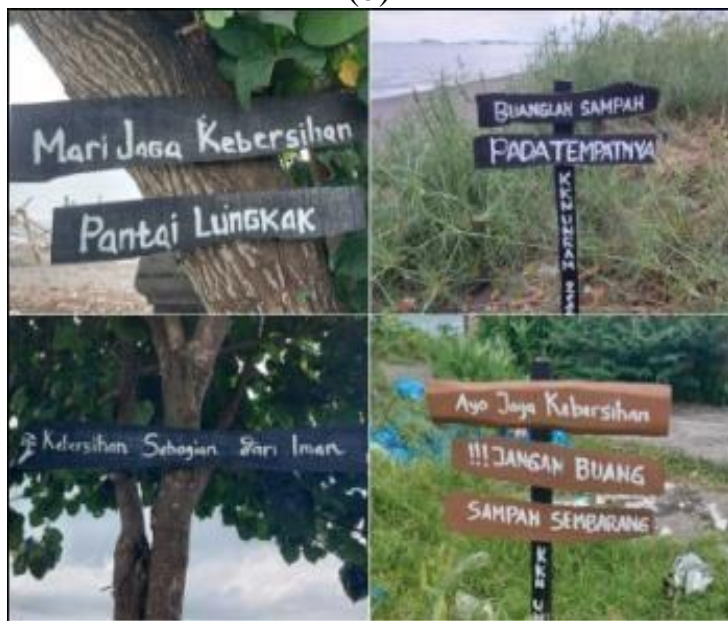

(c)

Gambar 2. (a) Papan penunjuk arah (b) Design papan informasi (c) Papan Himbauan.

\section{3) Pendamping wisata transit}

Pendampingan wisata transit ini merupakan kegiatan berbentuk diskusi dan pembuatan paket 
wisata bersama pengelola wisata di desa Ketapang Raya. Pendampingan wisata transit ini bertujuan untuk meningkatkan daya tarik wisatawan agar berkunjung dan melakukan perjalanan laut menuju beberapa destinasi wisata diantaranya lesehan apung, pantai tangsi, pantai segue, pulau pasir, gili gambir, pantai semangkok, gili sunut, dan telone bungalow.

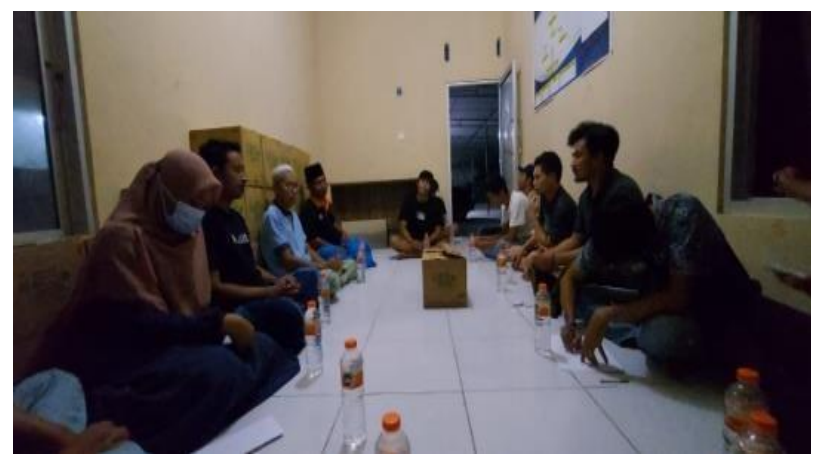

(a)

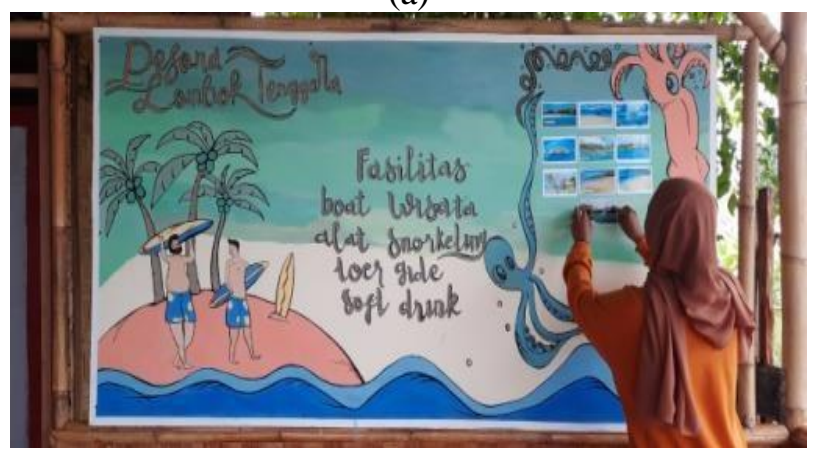

(b)

Gambar 3. (a) Diskusi bersama POKDARWIS (b) Design papan wisata transit.

\section{Kesimpulan}

Pelaksanaan kegiatan pengabdian pada masyarakat tentang pengembangan ekowisata di Desa Ketapang Raya dapat dirumuskan beberapa kesimpulan yaitu: Pengembangan ekowisata di Desa Ketapang Raya telah ada dalam struktur kelembagaan desa dan telah berperan secara aktif dalam mempromosikan destinasi wisata alam di Ketapang Raya. Selain itu, Desa Ketapang Raya memiliki empat destinasi alam unggulan yaitu wisata pantai, wisata Mangrove, tambak garam, dan budidaya lobster. Selain itu di desa Ketapang Raya tepatnya di pantai lungkak terdapat tempat transit ke beberapa destinasi wisata lainnya seperti lesehan apung, pantai tangsi, pantai segue, pulau pasir, gili gambir, pantai semangkok, gili sunut, dan telone bungalow. Masyarakat Desa Ketapang Raya telah memiliki pemahaman bahwa ekowisata adalah salah satu sumber mata pencaharaian yang potensial bagi masyarakat lokal dan bisa menekan angka pengangguran.

\section{Ucapan Terima Kasih}

Kelompok KKN Tematik UNRAM 2021 Desa Ketapang Raya mengucapkan banyak terimakasih kepada seluruh elemen desa yang telah membantu kami dalam merealisasikan semua program yang telah dibuat sehingga semuanya dapat terlaksana.

\section{Daftar Pustaka}

Ali, D. 2004. Pemanfaatan Potensi Sumberdaya Pantai Sebagai Obyek Wisata Dan Tingkat Kesejahteraan Masyarakat Sekitar LokasiWisata (Studi Kasus Di Kawasan Wisata Pantai Kartini Jepara). Program Pascasarjana Universitas Diponegoro. Semarang.

Budhyana, I. 2008. Kebijakan Disbudpar dalam Mengembangkan Kawasan Wisata di Jawa Barat. Makalah pada Seminar Pembangunan Kepariwisataan di Jawa Barat., Bandung: UPI.

Dias, S. 2009. Strategi Pengembangan Ekowisata Berbasis Ekonomi Lokal dalam Rangka Program Pengentasan Kemiskinan di Wilayah Kabupaten Malang. Jurnal of Indonesian Applied Economics, 3(1), 3747.

Moh Ilfan Setya Nur Chambali, Wisnu yudo untoro. 2007. Sistem Informasi Potensi Desa. Jurnal Ilmiah Teknik Informatika, Vol 2, No 2 .

Muhaimin, Suti'ah, dan Sugeng Listyo Prabowo. 2009. Manajemen Pendidikan, Jakarta: Kencana, h. 349

Sabhani, A. 2010. Potensi Objek Wisata Pantai di Kabupaten Lombok Timur tahun 2010. Tesis: Universitas Sebelas Maret Surakarta. 